\title{
PERENCANAAN DAN PELAKSANAAN ANGGARAN BERBASIS KINERJA KPU KABUPATEN BUNGO PADA PEMILIHAN KEPALA DAERAH DAN WAKIL KEPALA DAERAH TAHUN 2015
}

\author{
Dian Octapulia Sari ${ }^{1)}$, Syamsurizaldi²), Yuslim ${ }^{3}$ ) \\ 1,2,3) Megister Kosentrasi Tata Kelola Pemilu Fakultas Ilmu Sosial Dan Ilmu Politik \\ Universitas Andalas, Padang, Indonesia
}

\begin{abstract}
Abstrak
Sebelum dilaksanakannya Pilkada serentak, Pemeritah pernah melaksanakan Pilkada tidak langsung yang dipilih oleh DPRD, namun kebijakan Pemerintah membuat beberapa banyak pihak kecewa, karena dirasa masih kurang netral untuk pengambilan keputusan secara sepihak, maka pemerintah mengganti Pilkada menjadi secara langsung. Pada penelitian ini pengumpulan dokumen dilakukan dengan studi kepustakaan dan studi dokumen. Perpustakaan yang dikunjungi oleh peneliti untuk memahami tentang anggaran pilkada adalah perpustakaan Universitas Andalas, perpustakaan Pasca FISIP Universitas Andalas. Kemudian data yang diperoleh diambil dari bahan-bahan yang di downloud dari internet seperti journal dan e-book yang resmi yang berkaitan dengan permasalahan anggaran pilkada. secara umum KPU Kabupaten Bungo telah melaksanakan mekanisme dan prosedur perencanaan sudah baik. Dalam pembahasan terdapat regulasi yang belum jelas dalam penetapannya, sehingga antara tahapan dan pelaksanaan anggaran menjadi kacau dan tidak singkron.Penyebab dari anggaran kegiatan Pilkada yang tidak terealisasi dari Pemerintah Daerah ke KPU, disebabkan oleh tidak terealisasinya beberapa dana alokasi yang berasal dari APBN ke Pemerintah Daerah Kabupaten Bungo.Terjadinya anggaran bersama atau sharing anggaran dapat membantu anggaran hibah APBD Bungo menjadi lebihefisien. KPU Kabupaten Bungo berhasil melakukan pembenahan dan penyesuaian angka dalam laporan keuangan, sesuai dengan pagu yang sudah di revisi, dan sesuai dengan nilai NPHD yang telah di addendum.
\end{abstract}

Kata Kunci: Anggaran, Perencanaan, KPU, Pilkada

*Correspondence Address : dianahmadsaja@yahoo.co.id DOI : $10.31604 /$ jips.v6i2.2019.298-313

(C)2019 Fakultas Keguruan \& Ilmu Pendidikan UM-Tapanuli Selatan 


\section{PENDAHULUAN}

Pemilihan Umum Kepala Daerah (Pilkada) merupakan proses kedaulatan rakyat ditingkat lokal yang diatur berdasarkan Pasal 18 ayat (4) UndangUndang Dasar Negara Republik Indonesia Tahun 1945 (UUD NRI 1945) yang merupakan hak konstitusional seluruh warga negara Indonesia. Maka dari itu Pilkada wajib diselenggarakan secara berkualitas, dengan kondisi yang tertib, tentram dan aman. Pilkada juga selayaknya melahirkan Kepala Daerah yang berkualitas. Masih banyak dari beberapa daerah bahwa Pilkada yang seharusnya menjadi salah satu langkah kongkrit menuju demokrasi berubah menjadi ajang perebutan kekuasaan dan unjuk kekuatan semata. Kekuasaan adalah jala sekaligus ikannya. Maksudnya adalah barang siapa yang memiliki kekuasaan dengan mudah memperoleh segalanya, termasuk kekayaan, kehormatan, kesenangan, kenikmatan, dan fasilitas-fasilitas yang memungkinkan kemudahan.

Anggaran Pendapatan dan Belanja Daerah (APBD) yang dikelola harus berfungsi sebagai alat pembangunan sosial untuk mengentaskan kemiskinan, percepatan pembangunan infrastruktur dan dapat menunjang pelaksanaan aktivitas pemerintah daerah termasuk untuk kebutuhan Pilkada. Sehingga APBD tidak semata-mata menjadi sarana penyediaan modal pemerintah akan tetapi dapat didistribusikan untuk memobilisasi kegiatan pembangunan pada semua aspek kehidupan manusia. Hakikat APBD adalah milik rakyat dapat tercermin dari berapa besar kemauan politik pemerintah daerah dan DPRD untuk mengalokasikan sumber-sumber penerimaan daerah dan mendistribusikan untuk kepentingan publik.

Perencanaan pelaksanaan Pilkada pada tahun 2015 di Kabupaten Bungo melibatkan sejumlah lembaga tertentu dalam melaksanakan perencanaan anggaran. Badan Anggaran (Banggar) DPRD Kabupaten Bungo telah berkoordinasi dengan Tim Penyusunan Anggaran Pemerintah Daerah (TPAPD). Namun, anggaran yang digunakan untuk kegiatan Pilkada menjadi beban bagi APBD, karena yang pertama adalah siklus anggaran yang tak sesuai dengan siklus tahapan pilkada, yang kedua adalah ruang fiskal daerah terbatas. Dan selama ini Pilkada di biayai dari dana pengalihan belanja langsung yang awalnya untuk kepentingan publik.

Proses perencanaan dimulai dari Rencana Pembangunan Jangka Panjang 
Daerah (RPJPD) dengan memperhatikan Rencana Pembangunan Jangka Menengah Nasional. RPJPD merupakan suatu dokumen perencanaan pembangunan daerah untuk periode 20 (dua puluh) tahun yang digunakan sebagai acuan dalam penyusunan Rencana Pembangunan Jangka Menengah Daerah (RPJMD) untuk setiap jangka waktu 5 (lima) tahun. Setelah RPJMD ditetapkan, pemerintah daerah menyusun Rencana Kerja Pemerintah Daerah (RKPD) yang merupakan penjabaran dari RPJMD untuk jangka waktu 1 (satu) tahun yang mengacu kepada Rencana Kerja Pemerintah. Kepala daerah berdasarkan RKPD menyusun rancangan kebijakan umum APBD. Rancangan kebijakan Umum APBD yang telah dibahas kepala daerah bersama DPRD, selanjutnya disepakati menjadi Kebijakan Umum APBD (KUA). Berdasarkan kebijakan umum APBD yang telah disepakati, pemerintah daerah dan DPRD membahas rancangan prioritas dan plafon anggaran sementara (PPAS) yang disampaikan oleh kepala daerah. Kemudian Kepala daerah menerbitkan pedoman penyusunan Rencana Kerja dan Anggaran (RKA) SKPD sebagai pedoman kepala SKPD menyusun RKASKPD berdasarkan nota
kesepakatan.Setelah RKA-SKPD dibuat, selanjutnya adalah menyusun rencana peraturan daerah tentang APBD dan rancangan peraturan kepala daerah tentang penjabaran APBD. Rencana peraturan tersebut akan dievaluasi kemudian ditetapkan oleh kepala daerah menjadi peraturan daerah tentang APBD dan peraturan kepala daerah tentang penjabaran APBD

Dalam penganggaran peranan perencanaan sangat penting, karena perencanaan dinyatakan dalam bentuk input yang diperlukan untuk menjalankan aktifitas yang direncanakan. Jika perencanaan atau input sudah sesuai maka program yang diusulkan atau yang dibuat dapat mencapai tujuan, karena anggaran berbasis kinerja didasari dengan tujuan.Kemudian Untuk mendukung sistemPenganggaran Berbasis Kinerja diperlukanalat ukur kinerja yang jelas dan transparanberupa indikator kinerja (performance indicators).Selain indikator kinerja juga diperlukan adanya sasaran (target) yang jelas agar kinerjadapat diukur dan diperbandingkan sehinggadapat dinilai tingkat efisiensi dan efektivitas dari pekerjaan yang dilaksanakan. Sistem anggaran berbasis kinerja dianggap penting, karena dengan adanya 
anggaran berbasis kinerja dapat memperbaiki tata kelola keuangan pemerintahan dan instansi supaya lebih baik lagi.

\section{METODOLOGI PENELITIAN}

Jenis Penelitian yang akan dilakukan adalah kualitatif. Alasan peneliti menggunakan metode kualitatif adalah untuk dapat menjelaskan bagaimana pelaksanaan anggaran diperlukan metode penelitian yang sesuai. metode kualitatif dirasa mampu dalam menjelaskan parbandingan anggaran yang tedapat pada DIPA/ RKA dengan realisasinya, sehingga dapat mencerminkan bagaimana pelaksanaan anggaran pada KPU Kabupaten Bungo apakah sudah sesuai dengan dokumen yang terintegrasi dan peraturan atau standar yang berlaku.

\section{Tekhnik Pengumpulan Data}

Data penelitian kualitatif bersumber dari kata-kata atau perbuatan manusia, diperlukan cara atau tekhnik pengumpulan data. Dalam melakukan pengumpulan data pada penelitian ini, peneliti melakukan tekhnik pengumpulan data dengan Tekhnik wawancara dianggap penting oleh peneliti untuk mendapatkan data, keterangan dan penjelasan yang peneliti dapat dari orang yang berkompeten dirasa akan mendapat data yang lebih akurat, dari tekhnik wawancara akan mengungkap informasi yang belum terdokumentasi serta berguna untuk mencocokkan hasil pengumpulan data dari responden dan tekhnik pengumpulan data lainnya.

Pada penelitian ini pengumpulan dokumen dilakukan dengan studi kepustakaan dan studi dokumen. Perpustakaan yang dikunjungi oleh peneliti untuk memahami tentang anggaran pilkada adalah perpustakaan Universitas Andalas, perpustakaan Pasca FISIP Universitas Andalas. Kemudian data yang diperoleh diambil dari bahan-bahan yang di downloud dari internet seperti journal dan e-book yang resmi yang berkaitan dengan permasalahan anggaran pilkada.

Informan yang dipilih dalam penelitian adalah informan yang mengetahui bagaimana perencanaan dan pelaksanaan anggaran Pemilihan Kepala Daerah dan Wakil Kepala Daerah 2015 di Kabupaten Bungo.

Pemilihan informan dilakukan dengan sengaja (purposive sampling) yang diarahkan kepada mereka yang mengetahui dan terlibat langsung dalam proses perencanaan dan pelaksanaan anggaran pilkada Kabupaten Bungo tahun 2015. Adapun informan yang 
diwawancarai dalam penelitian ini adalah :

1. Ketua Komisi Pemilihan Umum Kabupaten Bungo

2. Sekretaris KPU Kabupaten Bungo

3. Kasubbag Umum, Keuangan dan Logistik

4. Kasubbag Program dan Data KPU Kabupaten Bungo

5. Staff Bagian Keuangan KPU Kabupaten Bungo

Triangulasi dilakukan dalam pengecekan data dari berbagai sumber datadengan berbagai cara dan berbagai waktu. Dalam penelitian ini menggunakantriangulasi sumber. Triangulasi Sumber, dimana peneliti menguji data yangdidapat dari narasumber dengan membandingkan antara satu narasumber dengan narasumber lainnya. Sesuai dengan tujuannya, trianggulasi ini dilakukan untukmenguji keabsahan data yang diperoleh melalui wawancara dengan pelaku yang terkait dengan perencanaan dan pelaksanaan anggaran Pilkada Kabupaten Bungo Tahun 2015. Untuk informan triangulasi adalah :

1. Kepala Bappeda Kabupaten Bungo

2. Kepala Sub Bidang Pengeluaran PPKD, BPKAD Kabupaten Bungo

3. Bagian Keuangan KPU Provinsi Jambi

\section{HASIL PENELITIAN DAN PEMBAHASAN}

Ada 3 (tiga) tingkatan dalam perencanaan Pemilu dan Pilkada yaitu, perencanaanstrategic planning, perencanaan ini terkait gambaran apa saja hal-hal yang ingin dicapai, mulai dari visi, misi, tujuan, program dan sebagainya dalam jangka waktu lima tahun kedepan. Kemudian perencanaan operasional, ini adalah rencana yang sangat rinci dalam mencapai tujuan, didalamnya terdapat dimensi program dan kegiatan, anggaran, personel, logistik, dan tempat. Yang ketiga yaitu perencanaan tahapan, program dan jadwal penyelenggaran Pemilu dan Pilkada, yang mana perencanaan ini harus berdasarkan perencanaan strategik dan perencanaan operasional, (Zetra, 2015 :18-19).

\section{Penyusunan}

Perencanaan anggaran Pilkada di KPU Bungo dilaksanakan sejak dibulan Oktober 2014, dan proses penyusunan anggaran pada KPU Bungo dilaksanakan oleh subbagian program dan data yang memiliki tugas dan kewajiban dalam kegiatan perencanaan, kemudian sebagai pengambil kebijakan yang dipercayakan kepada komisioner divisi perencanaan anggaran dan data. Subbagian Program dan Data juga 
mempunyai tugas dalam menyusun rencana kerja (Renja), dimana renja tersebut nantinya akan dijadikan dokumen dalam penyusunan DIPA KPU yang mempunyai dasar hukum UndangUndang Nomor 17 Tahun 2003 tentang Keuangan Negara, Undang-Undang Nomor 01 Tahun 2004 tentang Perbendaharaan Negara, dan UndangUndang Nomor 14 Tahun 2015 tentang APBN Tahun 2016.

Menguatkan teori penganggaran berbasis kinerja (performance budgetting) dalam Keuangan Negara RI, disebutkan dalam pasal 14 ayat (2) Undang-Undang Nomor 17 Tahun 2003, untuk menjamin penyelenggaraan Pemerintahan yang demokratis, transparan, akuntabel, efisien dan efektif diperlukan pemikiran yang dirancang sesuai dengan rencana strategis, visi, misi, tujuan, sasaran, program, dan kegiatan. Maka, diperlukan adanya dokumen perencanaan dan penganggaran yang saling berkaitan atau kelengkapan dokumen yang terintegrasi, seperti Renstra, Renja dan RKA KL. Berdasarkan telaah dokumen, KPU Kabupaten Bungo telah membuat Rencana Stretegis (Renstra) Tahun 2015 yang berakhir di Tahun 2019, karena renstra merupakan langkah awal dalam pelaksanaan akuntabilitas kinerja pada KPU Kabupaten Bungo.

\section{Untuk Program Peningkatan} Sarana dan Prasarana Aparatur : Komisi Pemilihan Umum Kabupaten Bungo mempunyai sasaran program (outcome) yang hendak dicapai adalah meningkatnya dukungan sarana dan prasarana Komisi Pemilihan Umum Kabupaten Bungo. Adapun indikator kinerja programnya yaitu : persentase dukungan sarana dan prasarana untuk memenuhi kebutuhan kerja pegawai yang berfungsi dengan baik.Kemudian Program Penguatan kelembagaan demokrasi dan Perbaikan proses politik. Program ini merupakan program teknik Komisi Pemilihan Umum, untuk Komisi Pemilihan Umum Kabupaten Bungo, sasaran program (outcome) yang hendak dicapai adalah: tersusunnya rancangan peraturan dan keputusan KPU, pendokumentasian informasi hukum, advokasi hukum dan penyuluhannya, dan terfasilitasinya penyelenggaraan tahapan Pemilu. Adapun indikator kinerja programnya adalah : persentase ketepatan waktu harmonisasi dan penyusunan KPU Kabupaten sesuai dengan SOP, serta persentase penyediaan dan penyajian dokumentasi dan informasi hukum.Peta Strategi Bungo merupakan suatu proses 
penggambaran atas dasar hubungan sebab akibat antara satu sasaran strategi dengan strategi lainnya untuk menguji alur pikir suatu strategi.

KPU Kabupaten Bungo juga telah menyusun indikator kinerja seperti input, output, maupun outcome yang terdapat didalam teori siklus pengukuran kinerja yaitu penciptaan indikator dimana penciptaan indikator kinerja dilakukan setelah perumusan strategi dan diharapkan pada setiap program dan kegiatan yang dilaksanakan sebagai dasar penilaian kinerja di dalam Rencana Kerja Anggaran (RKA). Berdasarkan Rancangan Anggaran Belanja (RAB) Pilkada yang telah dibuat oleh KPU yang dimulai dibulan Oktober 2014, pelaksanaan revisi DIPA pada tanggal 14 November 2014 dan kemudian angka di dalam DIPAsecara otomatis di input ke dalam RKA/KL, tentunya anggaran yang telah disusun juga sudah berdasarkan standar biaya Pemerintah Daerah. Secara keseluruhan dokumen Renstra, RKA pada KPU Kabupaten Bungo telah tersinkronisasi dengan baik.

Dalam rangka kegiatan Pemilihan Kepala Daerah dan Wakil Kepala Daerah Kabupaten Bungo terdiri dari 2 (dua) tahapan yaitu tahapan persiapan dan penyelenggaraan. Tahapan persiapan dalam Pemilihan Kepala Daerah dan Wakil Kepala Daerah Kabupaten Bungo merupakan langkah awal untuk memasuki tahapan penyelenggaraan. Secara garis besar tahapan persiapan terdiri dari 7 (tujuh) kegiatan yaitu :

1. Perencanaan Program dan Anggaran

2. Penyusunan Peraturan Penyelenggaraan Pemilihan

3. Sosialisasi/Penyuluhan/Bimbing an Tekhnis

4. Pembentukan PPK,PPS,dan KPPS

5. Pemantauan Pemilih

6. Pengolahan daftar Penduduk Potensial Pemilih Pemilu

7. Pemutakhiran Data dan Daftar Pemilih

Dari ke 7 (tujuh) tahapan persiapan dalam pelaksanaan Pilkada tersebut hanya satu yang akan peneliti angkat dan lebih terfokus pada tahap Perencanaan Program dan Anggaran, seperti pernyataan Mardiasmo (2009) bahwa anggaran merupakan alat perencanaan manajemen untuk mencapai tujuan organisasi sehingga organisasi akan tahu apa yang harus dilakukan dan kearah mana kebijakan akan dibuat. Dalam menjalankan tugas Komisi Pemilihan Umum Kabupaten Bungosebagai sarana pemilihan umum ditingkat Kabupaten/Kota yang 
berpedoman pada tahapan, program dan jadwal waktu penyelenggaraan Pilkada yang dikeluarkanoleh Komisi Pemilihan Umum. Hal ini mengacu kepada Peraturan KPU Nomor 2 tahun 2015tentang Perencanaan, Tahapan, Program dan Jadwal Penyelenggaraan Pemilihan Kepala Daerah dan Wakil Kepala Daerah , maka Komisi Pemilihan Umum Kabupaten Bungo mengadakan rapat kerja atau rapat pleno pada tanggal 16 Februari 2015 untuk membahas tahapan-tahapan dan jadwal guna persiapan penyelenggaraan pemilu, dalam rapat tersebut juga membahas tentang penetapan anggaran Pilkada yang telah di buat, penunjukan bendahara Hibah dan hal hal lain yang dianggap perlu.

Tujuan utama atas anggaran Pilkada serentak di Kabupaten Bungo Tahun 2015 adalah, anggaran tersebut dapat menjadi pertanggung jawaban bagi penerima anggaran atas pelaksanaan kegiatan Pilkada bagi lembaga tekait, terkhusus bagi KPU Kabupaten Bungo, kemudian anggaran tersebut dapat menjadi informasi untuk kebutuhan Pemerintah Daerah dan DPRD serta KPU selaku pihak yang merencanakan dan melaksanakan Pilkada di Kabupaten Bungo, yang mana melibatkan tim Badan Anggaran bersamaan dengan Tim Penyusun Anggaran Pemerintah Daerah Kabupaten Bungo, selain sudah menjadi ketentuan dalam tahapan penyusunan anggaran, juga mencipatakan transparansi dalam pelaksanaan anggaran, sejalan dengan pernyataan Mardiasmo (2006:18)yang mendefinisikan bahwa transparansi adalah “ keterbukaan (opennesess) pemerintah dalam memberikan informasi yang terkait dengan aktivitas pengelolaan sumber daya publik kepada pihak-pihak yang membutuhkan informasi. Pemerintah berkewajiban memberikan informasi keuangan dan informasi lainnya yang akan digunakan untuk pengambilan keputusan oleh pihak-pihak yang berkepentingan. Terkhusus dana anggaran Pilkada yang anggarannya memang terbilang fantastik, namun Pemerintah Daerah Kabupaten Bungo dalam segi informasi yang transparan telah dilaksanakan dengan memberikan data dan informasi kepada media cetak dan elektronik, sehingga masyarakat mengetahui berapa jumlah anggaran Pilkada yang dipakai saat itu.

Hal yang mendasari DPRD membahas dan melakukan persetujuan terhadap anggaran yang diajukan oleh KPU Bungo melalui TAPD Muara Bungo, 
adalah karena aturan hukum atau regulasi dan kemampuan keuangan daerah yang menjadi hal utama, kemudian disamping mendapat informasi yang jelas tentang proses pengajuan Pilkada atau prosedur yang sesuai dengan aturan yang berlaku. Hal ini, seperti diungkapkan oleh Mullins (2007) bahwa tahapan kristis dalam pembahasan yang dilakukan oleh legislatif dan persetujuan terhadap pengajuan proposal aggaran yang dilakukan adalah kualitas dari informasi penganggaran proposal berkenaan.

Setelah pengajuan anggaran disetujui oleh TAPD dan DPRD, maka KPU dan pemerintah daerah Kabupaten Bungo membuat kesepakatan melalui Naskah Perjanjian Hibah Daerah (NPHD) dengan nomor : 900/202/bpkad/2015 dan nomor 126 /kpu.kab/ 005.656450/ V/2015 tanggal 18 Mei 2015 tentang pemberian hibah dana penyelenggaraan Pemilihan Bupati dan Wakil Bupati Tahun 2015. Dengan disaksikan dari Pemerintah Daerah dan KPU Kabupaten Bungo. NPHD dilampiri dengan fakta integritas dari penerima Hibah yang menyatakan bahwa hibah yang diterima akan digunakan sesuai dengan NPHD.

\section{Proses Pelaksanaan Anggaran Pilkada Tahun 2015}

Dalam penelitian ini ditemukan fakta baru bahwasanya anggaran yang digunakan untuk pelaksanaan Pilkada serentak di Provinsi Jambi menggunakan anggaran bersama atau sharing anggaran, yang mana memang sudah diatur di dalam Permendagri Nomor 44 Tahun 2015. Berbeda dengan penelitian sebelumnya dari Hendri Koeswara, Ira Irawati, dan Arry Bainus (2018) dengan judul penelitiannya Analisis Anggaran Pelaksanaan Pemilihan Walikota Solok Pada Pilkada Serentak Nasional Tahun 2015, dengan hasil temuannya bahwasanya Pemilihan Kota Solok tidak terjadi pendanaan bersama dan menanggung beban anggaran dari masing-masing daerah yang melaksanakan Pilkada serentak, Kegagalan pendanaan bersama antara PilkadaKota Solok dengan Pilgub Sumatera Barat ini menurut penulis karena terlambatnya pelbagaiatau variasi kebijakan yang dikeluarkan oleh pemerintah tentang hal tersebut. Didalam Permendagri Nomor 44 Tahun 2015 Pasal 4 tertulis :

1. Pemerintah Provinsi dapat membantu pendanaan kegiatan Pemilihan Bupati danWakil Bupati/Walikota dan Wakil Walikota 
dalam hal Pemerintah Kabupaten/Kota mengalami keterbatasan kemampuan keuangan daerah untuk penyelenggaraan kegiatan Pemilihan Bupati dan Wakil Bupati/Walikota danWakil Walikota.

2. Pemerintah Kabupaten/Kota dapat membantu pendanaan kegiatan Pemilihan Gubernur dan Wakil Gubernur dalam hal Pemerintah Provinsi mengalamiketerbatasan kemampuan keuangan daerah untuk kegiatan Pemilihan Gubernur dan Wakil Gubernur.

\section{Permintaan Dana Hibah}

Berdasarkan hasil penelitian dan tata cara pelaksanaannya (SOP), KPU Kabupaten Bungo juga harus mengikuti prosedur dan sistem yang berlaku. Untuk mengajukan permohonan permintaan dana hibah ke Pemerintah Daerah sesuai dengan yang di syaratkan dalam NPHD dengan melampirkan foto copy KTP, rekening koran dan surat pertanggung jawaban dari bendahara Hibah Kepada Dinas Pengelolaan Keuangan dan Aset Daerah (DPKAD) Kabupaten Bungo. Pencairan dana hibah untuk kebutuhan kegiatan Pilkada dilakukan dalam 3 (tiga) tahapan dengan ketentuan KPU Kabupaten Bungo dapat meminta pendanaan kembali dengan menyampaikan bukti penggunaan dana hibah atau daftar kebutuhan kegiatan Pilkada.

Setelah DPKAD menerbitkan Surat Perintah Pencairan Dana (SP2D), maka KPU Kabupaten Bungo berhak menerima transferan dana hibah ke rekening yang sudah dilaporkan dengan nomor rekening adalah 0201014743 dan nama rekening adalah RPL $078 \mathrm{KPU}$ KAB.BUNGO UH PILKADA 2015, dana hibah di transfer sesuai dengan tahapan yang sudah disesuaikan berdasarkan tahapan yaitu 3 (tiga) kali yaitu yang pertama tanggal 01 Juni 2015 yang ke 2 (dua) tanggal 04 November 2015 dan yang ke 3 (tiga) tanggal 21 Desember 2015, dan KPU wajib mempertanggung jawabkan dana yang telah terpakai sesuai dengan kebutuhan dan penggunaan (akan diuraikan pada pembahasan selanjutnya). Kemudian dana hibah KPU Bungo harus telah mengacu pada standar biaya harga kebutuhan pendanaan kegiatan pemilihan yang telah ditetapkan dengan keputusan daerah. Berdasarkan beberapa hasil wawancara bersama informan kunci bahwasanya dana hibah yang dipakai untuk kegiatan Pilkada sudah berdasarkan standar biaya daerah setempat yang mengacu pada pedoman peraturan daerah yaitu Peraturan Bupati Kabupaten Bungo Nomor 18 
Tahun 2015 tentang penetapan standar biaya di Lingkungan Pemerintahan Kabupaten Bungo.

Dikarenakan mekanisme yang diterapkan dalam sitem penganggaran Pilkada serentak berbeda dengan sistem penganggaran Pilkada sebelum serentak, dimana KPU Kabupaten Bungo dan KPU lainnya harus mengajukan registrasi dana hibah terlebih dahulu dengan merujuk padaPeraturan Menteri Keuangan Nomor 191/PB.05/2011 tentang mekanisme Pengelolaan Hibah mengatur Kementrian/Lembaga/Satuan Kerja Pemerintah Pusat yang menerima Hibah diwajibkan untuk melaporkan penerimaan hibah langsung berupa uang/barang baik yang dibiayai dari dalam negeri atau luar negeri.

\section{Penerimaan Dana Hibah Pilkada dan Proses Registrasi}

KPU Kabupaten Bungo sebagai Satuan Kerja Pusat wajib melaporkan penerimaan Hibah Pemilihan Kepala Daerah dan Wakil Kepala Daerah Tahun 2015 kepada Ditjen Pengelolaan Pembiyaan dan Resiko cq. Direktur Evaluasi, Akuntansi dan Setelmen di Jakarta dengan terlebih dahulu mengajukan Surat Permohonan; Ringkasan Hibah dan NPHD yang telah dilegalisir untuk diterbitkan Nomor
Register Hibah. Dan KPU Kabupaten Bungo saat itu telah melakukannya yang bepergian saat itu adalah Sekretaris KPU dan Bendahara KPU pada tanggal 5 Juli 2015. Proses registrasi hibah merupakan entry point untuk memasukan Hibah dalam mekanisme APBN dan diakui sebagai Pendapatan Hibah Langsung bagi KPU Kabupaten Bungo, tanpa adanya nomor register akan berpengaruh terhadap proses pengesahan hibah selanjutnya. Nomor Register Hibah adalah : S1371/PR.8/2015 Tanggal 06 Juli 2015 dengan Nomor : 2WEJLCH9

\section{Proses Pengesahan Pendapatan Hibah Langsung (SP2HL)}

Dalam proses pengesahan pendapatan hibah pada Pilkada serentak ada yang namanya Surat Pernyataan Pengesahan Hibah Langsung (SP2HL) yang mana KPU Kabupaten Bungo juga melakukan proses pengesahan hibah melalui KPPN, KPU Kabupaten Bungo mengajukan pengesahan atas seluruh Pendapatan Hibah Langsung yang diterima dari Pemerintah Daerah Kabupaten Bungo untuk Pendanaan Pemilihan Kepala Daerah dan Wakil Kepala Daerah Tahun 2015 dalam bentuk uang sebesar yang telah ditransfer atau diterima kepada KPPN 
Bungo. Pengesahan atas Pendapatan Hibah Langsung dilakukan sebanyak 3 (tiga) kali pengesahan, yakni pada akhir Tahun Anggaran 2015 sebanyak 2 (dua) kali serta pada Tahun 2016 sebagai akhir pelaksanaan kegiatan Pemilihan Kepala Daerah dan Wakil Kepala Daerah Tahun 2015.

Faktor yang menyebabkan terhambatnya proses pelaksanaan anggaran pada Kabupaten Bungo adalah dikarenakan tidak terealisasinya anggaran seutuh nya dari Pemerintah Daerah ke KPU Kabupaten Bungo, sehingga KPU harus melakukan banyak pembenahan dan penyesuai angka untuk menyingkronkan data-data yang sesungguhnya. Proses ini dinamakan penyempurnaan ukuran, dimana pada tahap ini dilakukan pemikiran kembali atas indikator kinerja dan indikator dampak agar menjadi lebih penting, dan ini sesuai dengan siklus kinerja yang diterapkan oleh Mardiasmo (2009)

\section{Proses Pengesahan Pengembalian} Sisa Anggaran (SP4HL)

Dalam pelaksanaan anggaran Pilkada KPU Kabupaten Bungo, bendahara juga melakukan proses pengesahan (SP4HL) melalui KPPN pada tanggal 27 Juni 2016, dimana SP4HL ini adalah laporan berupa sisa dana hibah Pilkada yang disetor ke Rekening Kas
Daerah pada tahun aggaran 2016 yag sesuai tercantum didalam NPHD Atas dasar bukti setor sisa dana Hibah, KPU Kabupaten Bungo membuat Surat Perintah Pengesahan Pengembalian Pendapatan Hibah Langsung (SP4HL) ke KPPN dengan melampirkan Copy Rekening Koran Hibah; copy Bukti Penyetoran ke Rekening Pemberi Hibah dan SPTJM. Atas dasar SP4HL tersebut ke KPPN Bungo menerbitkan Surat Pengesahan Pengembalian Pendapatan Hibah Langsung (SP3HL) untuk disampaikan kepada KPU Kabupaten Bungo dan dibukukan sebagai pengurang saldo kas di K/L dari Hibah by Aplikasi SAIBA.

\section{Proses Revisi DIPA dalam Penyelenggaraan Pilkada}

Dalam pelaksanaan anggaran Pilkada Tahun 2015, KPU Kabupaten Bungo telah melakukan revisi RKA dan revisi DIPA, revisi RKA hibah dilakukan hanya sebatas KPU dan Pemerintah Daerah, tetapi revisi DIPA adalah revisi yang dilakukan melalui aplikasi RKA/KL dan langsung terhubung dengan Kemenkeu, yang dilakukan sebanyak 2 (dua) kali. Revisi DIPA pertama dilakukan dengan Nomor SP.DIPA076.01.2.656450/2015 Tanggal 14 November 2014, berdasarkan pada 
Peraturan Menteri Keuangan

Nomor.191/PB.05/2011

tentang

Mekanisme Pengelolaan Dana Hibah.

\section{Proses Penutupan Rekening}

\section{Anggaran APBD}

Dalam pelaksanaan proses penutupan rekening anggaran pada KPU Kabupaten Bungo juga melalui KPPN Bungo, dilakukan berdasarkan Peraturan Menteri Keuangan No. 252/PMK.05/2014 Tentang Pengelolaan Rekening kementerian/ Lembaga/ Satuan Kerja, bagi Satuan Kerja yang memiliki rekening yang tidak digunakan lagi sesuai dengan pembukaannya wajib melakukan penutupan rekening kepada Bank yang telah ditentukan dalam perjanjian. Berakhirnya proses kegiatan Pemilihan Kepala Daerah dan Wakil Kepala Daerah Kabupaten Bungo, KPU Bungo sebagai penerima Hibah melakukan Permohonan Penutupan Rekening pada Bank BPD Cabang Bungo.

\section{Proses Pembenahan dan}

\section{Penyempurnaan}

Dari berbagai kendala yang terjadi di KPU Kabupaten Bungo, yang di dasari dari tidak terealisasinya anggaran seluruhnya dari Pemerintah Daerah ke KPU memang telah menjadi pusat perhatian terkhusus di Provinsi Jambi, karena dari 5 Kabupaten yang melaksanakan Pilkada serentak saat itu hanya Bungo saja yang terjadi permasalahan tersebut.

\section{Penerapan Prinsip Anggaran Berbasis Kinerja}

KPU Kabupaten Bungo dalam rangka meningkatkan Transparansi dan Akuntabilitas dalam pelaksanaan anggaran, telah menggunakan Aplikasi Sistem Monitoring dan Informasi Keuangan (SIMONIKA) yaitu aplikasi yang menyajikan Laporan Pertanggung Jawaban Penggunaan Anggaran, kemudian yang mengoperasikan aplikasi ini di KPU Bungo adalah staff Pembantu Bendahara rutin (076). Manfaat dari pelaporan dengan menggunakan aplikasi SIMONIKA ini adalah untuk memudahkan pekerjaan bendahara KPU dalam membuat Laporan Hibah dan Laporan anggaran rutin. Laporan ini digunakan secara elektronik dan terprogram, dan mekanisme penggunaannya adalah dengan menggunakan jaringan internet dibuka melalui media komputer, tablet atau handpone

Dilihat dari Laporan Realisasi Anggaran KPU Kabupaten Bungo yang dipaparkan dalam pembahasan sebelumnya dengan angka capaian 99,78\% dari seluruh kegiatan yang dilakukan oleh Komisi Pemilihan Umum 
Kabupaten Bungo merupakan capaian angka yang relatif baik. Komisi Pemilihan Umum telah melakukan anggaran seefektif mungkin, menurut Mardiasmo (2009:132). Efektivitas merupakan hubungan antara keluaran dengan tujuan atau sasaran yang harus dicapai. Kegiatan operasional dikatakan efektif apabila proses kegiatan mencapai tujuan dan sasaran ahir kebijakan spending wisely, maka kesimpulan berdasarkan dari hasil penelitian melalui Laporan Realisasi Anggaran (LRA) KPU Kabupaten Bungo dalam pelaksanaan anggarannya adalah efektif dan efisien.

Komisi Pemilihan Umum Kabupaten Bungo telah melakukan prinsip pendekatan kinerja, terbukti bahwasanya KPU Bungo telah melakukan outcome dari Program Penguatan Kelembagaan Demokrasi dan Perbaikan Proses Politik yaitu terfasilitasinya penyelenggaraan tahapan Pemilu, dan Pilkada, dan dengan indikator kinerja adalah persentase ketepatan waktu harmonisasi dan penyusunan KPU Kabupaten sesuai dengan SOP, serta persentase penyediaan dan penyajian dokumentasi dan informasi hukum. Pelaksanaan anggaran di KPU Kabupaten Bungo telah berhasil melakukan efektifitas dalam penggunaan anggaran, dan dapat menekan biaya di bawah standar pagu,karena keberhasilan tidak ditentukan dengan habis atau tidaknya anggaran melainkan ditentukan oleh tercapai atau tidaknya indikator kinerja yang telah ditetapkan".

\section{Kesimpulan Dan Saran}

Berdasarkan hasil penelitian ini menyimpulkan bahwa, secara umum KPU Kabupaten Bungo telah melaksanakan mekanisme dan prosedur perencanaan sudah baik namun dalampelaksanaan anggaran berdasarkan anggaran berbasis kinerja belum baik, namun ada beberapa poin yang dapat disimpulkan dari hasil penelitian dan pembahasan didalam pelaksanaan anggaran adalah :

1. Dalam pembahasan terdapat regulasi yang belum jelas dalam penetapannya, sehingga antara tahapan dan pelaksanaan anggaran menjadi kacau dan tidak singkron

2. Penyebab dari anggaran kegiatan Pilkada yang tidak terealisasi dari Pemerintah Daerah ke KPU, disebabkan oleh tidak terealisasinya beberapa dana alokasi yang berasal dari APBN ke Pemerintah Daerah Kabupaten Bungo. 
3. Terjadinya anggaran bersama atau sharing anggaran dapat membantu anggaran hibah APBD Bungo menjadi lebih efisien.

4. KPU Kabupaten Bungo berhasil melakukan pembenahan dan penyesuaian angka dalam laporan keuangan, sesuai dengan pagu yang sudah di revisi, dan sesuai dengan nilai NPHD yang telah di addendum.

Berdasarkan Kesimpulan yang telah dikemukakan diatas, beberapa saran terkait Perencanaan dan Pelaksanaan Anggaran berbasis Kinerja :

1. Regulasi dan kebijakan yang dikeluarkan, baik itu dari Permendagri, atau PKPU atau kebijakan lainnya harus tepat pada waktunya dalam penetapan.

2. Penelitian ini merekomendasikan bahwa untuk anggaran Pilkada serentak ditempatkan di APBN

3. Pemerintah dan KPU harus mempertimbangkan anggaran bersama atau sharing anggaran, untuk meminimalisir kekeliruan dalam penyusunan dan pengelolaan anggaran

4. Dirasa perlu untuk didatangkan pelatih ke KPU daerah dari pusat, untuk melaksanakan bimbingan dalam penyusunan dan pengelolaan anggaran Pilkada
5. KPU harus meningkatkan kerjasamanya dan koordinasi yang lebih baik lagi antar Komisi Pemilihan Umum dan Pihak Pemerintah.

6. Komisi Pemilihan Umum dalam membuat regulasi, tahapan Pemilu dan kebijakan diharapkan tidak sering diubah-ubah karena sangat mempengaruhi dalam penentuan keputusan di tingkat daerah.

\section{Daftar Pustaka}

Ade Putra. 2017. Implementasi anggaran pemilihan kepala daerah serentak pada pemilihan Gubernur dan wakil Gubernur Provinsi Jambi 20015. Tesis, Universitas Lampung

Abdul Halim dan Syam Kusufi. 2012. Akuntansi Sektor Publik : Teori, Konsep, dan Aplikasi, Salemba Empat: Jakarta

Ahmad Zainuri.2018. Akuntabilitas Pengelolaan Anggaran pada Komisi Pemilihan Umum (KPU) Kota Cilegon, Program Studi Administrasi Publik Fakultas Ilmu Sosial Ilmu Politik dan Ilmu Hukum.Universitas Serang Raya.

Andrie Fajar.2017. Akuntabilitas Pengelolaan keuangan Komisi Pemilihan Umum Kabupaten Konawe, Mahasiswa PSP Program Studi Tata Kelola Pemilu Pascasarjana UNSRAT

Alan Wall, Andrew Ellis, Ayman Ayoub, Carl W. Dundas, Joram Rukambe, Sara Staino Electoral, 2006 Management Design, The International IDEA Handbook. Stockholm

Abdul Halim, 2007 Akuntansi Sektor Publik, Akuntansi Keuangan Daerah, Salemba Empat, Jakarta, 2007 
Dian Octapulia Sari, Syamsurizaldi, Yuslim

Perencanaan Dan Pelaksanaan Anggaran Berbasis Kinerja Kpu Kabupaten Bungo Pada Pemilihan .....

Bastian, Indra.2006. Sistem Akuntansi Sektor Publik Edisi 2. Jakarta: Salemba Empat

Eftriani, Z, 2014, Proses Perumusan Anggaran Belanja Hibah dan Bantuan Sosial APBD Provinsi Kepulauan Bangka Belitung. Tesis, Universitas Gadjah Mada

Efri Nofrita. 2018. Politik Anggaran Pilkada KPU Provinsi Sumatera Barat Tahun 2015, Konsentrasi Tata Kelola Pemilu Program Magister Ilmu Komunikasi Fakultas Ilmu Sosial dan Ilmu Politik Universitas Andalas.

Garrison, H. Ray; Eric W. Noreen; dan Peter C. Brewer. 2006. Akuntansi Manajerial. (terjemahan: A. Totok Budisantoso). Buku I Edisi Kesebelas. Salemba Empat. Jakarta.

Halim, Abdul. 2007. Pengelolaan Keuangan Daerah. Yogjakarta: UPP STIM YKPPN

Hasan, M. Iqbal, Pokok-pokok Materi Metodologi Penelitian dan Aplikasinya, Ghalia Indonesia, Bogor, 2002 hal 82

HamsanJani. 2015. Tinjauan Tentang Kinerja Komisi Pemilihan Umum Daerah dalam Pelaksanaan Pemilihan Presiden dan Wakil Presiden Tahun 2014 di Kabupaten Paser, eJournal Ilmu Pemerintahan.

Kementerian Negara
Pembangunan
$\begin{aligned} & \text { Perencananan } \\ & \text { Nasional/Badan }\end{aligned}$
(BAPPENAS). 2009. Buku Pedoman
Penerapan Anggaran Berbasis Kinerja,
Jakarta

Moleong, j, Lexy. 2006. Metodologi Penelitian Kualitatif. Bandung: PT. Remaja Rosdakarya.

Mardiasmo. 2002. Ekonomi Dan Manajemen Keuangan Daerah, Penerbit ANDI Yogyakarta

Mardiasmo.2005. Akuntansi Sektor Publik. Yogjakarta. Andi Yogjakarta.
Mardiasmo. 2006. Perpajakan. Andi Offset. Yogjakarta.

Mardiasmo. 2009, Akuntansi Sektor Publik, Yogjakarta: Andi

Mahsun, M. 2006. Pengukuran Kinerja Sektor Publik. Yogyakarta: BPFE

Manulang. 1990. Dasar-Dasar Manajemen, (Jakarta: Galia Indonesia).

Mullins, John W. Walker Jr., Orville, C., dan Boyd Jr., Harper W. 2008. Marketing Management: A Strategic Decision Making Approach 6thed. New York: McGraw Hill.

Rasul, Syahrudin, 2003 Pengintegrasian Sistem Akuntabilitas Kinerja dan Anggaran dalam Perspektif UU NO. 17/2003 Tentang Keuangan Negara. Jakarta: PNRI

Sri Nuryanti.2015. Intervensi Penyelenggaraan Pemilukada: Regulasi, Sumber daya, dan Eksekusi. Jurnal Ilmu Sosial dan Ilmu Politik.

Usep Hasan Sadikin. 2016. Menyerentakan Pemilu, Memusatkan Anggaran Pilkada, Perludem, Jakarta.

Zatriawati.2017. Yunus Sading, Vita Yanti Fattah, Pengelolaan Anggaran Pemilihan Kepala Daerah Pada Komisi Pemilihan Umum Kota Palu Tahun 2015. Mahasiswa Program Studi Magister Pembangunan Wilayah Perdesaan Pascasarjana Tadaluko, Dosen Program Studi Magister Pembangunan Wilayah Perdesaan Pascasarjana Tadaluko.

Zetra.2015. Pengelolaan Keuangan Pemilu. Modul Pembelajaran Tata Kelola Pemilu. Fisipol Universitas Andalas. 